\title{
Antecedent Variables and Consequences of Religiosity on Fraud
}

\author{
Muhamad Taqi ${ }^{1}$, Sabaruddinsah $^{1}$, Tubagus Ismail ${ }^{1} \&$ Meutia $^{1}$ \\ ${ }^{1}$ University of Sultan Ageng Tirtayasa, Indonesia Center of Excellence For Food Security, Banten, Indonesia \\ Correspondence: Tubagus Ismail, University of Sultan Ageng Tirtayasa, Indonesia Center of Excellence For Food \\ Security, Banten, Indonesia.
}

Received: July 30, 2019

Accepted: August 26, 2019

Online Published: October 16, 2019

doi:10.5430/ijfr.v11n1p43

URL: https://doi.org/10.5430/ijfr.v11n1p43

\begin{abstract}
This study aims to analyze the antecedent variables of religiosity (suitability of compensation, money ethics and internal control system) and the consequences on accounting fraud among regional officials. The study method used here was descriptive quantitative method with a correlation approach, the sampling used purposive sampling technique. Data collection in this study was conducted by distributing questionnaires to the officials of the Regional Work Units (SKPD) of Serang City and Regency. Data analysis used Structural Equation Modelling (SEM) with SmartPLS program. The results of the study showed that the suitability of compensation had a negative effect, money ethics had a positive effect, the internal control system had a negative effect and religiosity had a negative effect on accounting fraud among the regional officials. Then the suitability of compensation, money ethics and internal control systems were proved to be the antecedent variables of religiosity.
\end{abstract}

Keywords: suitability of compensation, money ethics, internal control system, religiosity and accounting fraud

\section{Introduction}

In the current era of globalization, every country has its own strategies and systems in an effort to achieve its goals, and so does Indonesia. Currently, Indonesia implements a regional autonomy system, where each region has the right, authority and obligation to regulate government affairs and the interests of the local community in accordance with the laws and regulations starting from the provincial level to the sub-district level.

The impact of the implementation of autonomy system finally resulted in several changes that occurred in the relationship between the executive and the legislative. First, executives and councils have full autonomy to make local policies; and second, council members have full autonomy and have a big role in the legislative process. The authority of the council in making policies is not limited to making laws, but also supervision, investigation, and together with executives compiling APBD that were not previously carried out..

However, the euphoria of regional autonomy turned out to have many negative impacts. One that stands out is the emergence of institutional crime, both executive and legislative. One crime that is often carried out in the form of accounting fraud is related to corruption. Ccorruption among bureaucrats is indeed difficult to avoid, because political scandals on power and bureaucracy really played a very large role.

Study on accounting fraud related to corruption is an important topic, because the act of handling accounting fraud requires a better, comprehensive and integrated effort. For this reason, the things that need to be traced are the main causes of accounting fraud to get more complete information about the causes of the occurrence of accounting fraud.

One of the factors directly related to the occurrence of accounting fraud is the suitability of compensation given to employees as remuneration for their contributions to the organization. With appropriate compensation, the behavior of accounting fraud can be reduced, so that individuals are expected to get satisfaction from the compensation, and not conduct unethical behaviors and act fraudulently to maximize personal benefits.

However, sometimes accounting fraud does not only due to compensation suitability, but it is also because influenced by the high love of having money. According to Sloan (2002) love of money is due to someone put money as a top priority in his daily life. He will feel that accounting fraud is an acceptable action (Lau et al., 2013). People who had a very high love of money were mentally more involved in deviant behaviours within organizations (Tang \& Chiu, 2003), since they were motivated to earn more money. 
According to Tang (2002) money ethics was directly related to fraud accounting. This can be interpreted that the more a person prioritized money as an important thing (high money ethics), the person was more likely to commit unethical accounting fraud than a person who had low money ethics.

To reduce the accounting fraud, an effective internal control system is needed. The internal control system is expected to reduce accounting fraud, because effective internal control can play an important role in the organization to minimize fraud (Meutia, 2017).

However, in fact the application of an effective internal control system in Indonesia had not yet reduced accounting fraud, therefore Ismail et al. (2018) suggested to apply relevant principles and values. Specifically McGuire et al. (2011) stated the importance of returning to religious beliefs in forming attitudes in activities, because accounting fraud itself was considered an action that violated religion/non-ethical actions conducted by regional officials.

The problem in this study is that there are still differences in the results of studies on accounting fraud in Indonesia, namely the suitability of compensation. The suitability of compensation variable had an effect on accounting fraud, but the results of a study conducted by Meutia (2017) stated that the suitability of compensation did not have effect on accounting fraud.

Besides, the problem of this study is also based on several previous studies conducted who examined the factors that influenced accounting fraud. More in-depth study showed that there was still a lack of empirical studies regarding the effect of money ethics variable on accounting fraud with religiosity as a moderating variable. Therefore, this study used the religiosity variable as a moderating variable because according to Grasmick et al. (1991) religiosity acts as a stronger prevention than the fear of legal sanctions. Religiosity applies as a mechanism for enforcing internal moral rules that can limit individual intentions to commit accounting fraud.

\section{Literature Review and Hypotesis Development}

\subsection{Effect of Suitability of Compensation on Accounting Fraud}

In attribution theory, someone actions in the organization are influenced by causal attributes. The fraudulent actions taken by a person are caused by the desire to maximize personal benefits, because basically people work to earn money to meet their needs. For this reason, an employee works to show loyalty to the company with the hope that the company gives awards to him. One way of management to improve work performance, motivate, and improve employee performance is through compensation (Ismail et al., 2019).

Compensation is a component of costs paid by the organization to employees. For employees, compensation is a factor that determines the level of welfare, while for organizations, compensation is a component of costs that affect the level of efficiency and profitability. Therefore, organizations need to be careful in controlling and designing compensation so that both interests can be accommodated. This is a challenge for organizations to create a compensation system that is able to encourage employees to perform optimally (Leopold, 2000).

Accounting fraud is driven by individual dissatisfaction with the rewards they get from the work they do. The appropriate compensation system is expected to make individuals feel sufficient, so that individuals do not take actions that harm the organization including conducting accounting fraud, because suitable compensation is expected to reduce the desire to commit fraudulent actions. Based on the description, the study hypothesis can be derived as follows:

H1: There is an effect of the suitability of compensation on accounting fraud among regional officials.

\subsection{Effect of Money Ethics on Accounting Fraud}

According to Tang (2002), people who had high money ethics would place money as important, and would be less ethical than people who had low money ethics. So by having a lot of money, some people have higher satisfaction needs and can enjoy a better standard of living. Therefore, they try to make more money to maintain their lifestyle.

A person's love for money motivates these people to engage in unethical behaviour (Tang, 2002), one of which is to commit accounting fraud. When someone emphasizes the importance of money and acquired wealth, they will feel that unethical behaviour is acceptable. Someone who is highly motivated by money or who places money as a top priority will believe that accounting fraud is an ethical act.

Previous study showed that money ethics had a significant and direct impact on fraud, Lau et al. (2013), because they assumed that the act of cheating was normal. This meant that the higher the level of love someone had for money, the higher the chance for someone to commit an accounting fraud. Based on the description, the study hypothesis can be derived as follows: 
$\mathrm{H} 2$ : There is an effect of money ethics on accounting fraud among regional officials

\subsection{Effect of Internal Control System on Accounting Fraud}

Attribution theory explains that the actions of a leader and the person given authority are influenced by causal attributes. Therefore, a control system is needed to reduce the causes of fraud.

The internal control system is expected to be able to reduce the deviant actions taken by employees because some employees tend to take deviant actions to maximize personal benefits. One example of deviant actions is to commit accounting fraud.

Accounting fraud can occur if there is an opportunity to do so. Big opportunities make accounting fraud more common. This opportunity can be reduced by a good internal control system (Cohran, 1998). Effective internal control can reduce or even close the opportunity to commit accounting fraud. Based on the description, the study hypothesis can be derived as follows:

H3: There is an effect of internal control system on accounting fraud among regional officials.

\subsection{Effect of Suitability of Compensation, Money Ethics and Internal Control System on Accounting Fraud Among Regional Officials When Mediated by Religiosity Variable}

Religiosity acts to reduce and even prevent deviant behaviour, one of which is accounting fraud. Prevention can be made possible, because people who have high religiosity will have strong self control, since the religious teachings they believe prohibit these actions. The role of religion in the prevention of deviant behaviour was put forward by Cohran (1988; Desmond et al. (2013).

According to Ismail (2018) people who had a strong religious orientation would not take actions that harm others, because in their lives they did not want to harm others. If acts of harming others are exemplified by acts of corruption, people who have religious understanding and beliefs (religiosity) will not perform these actions, even though they have the opportunity to commit accounting fraud.

Individuals who have a religious orientation view that fraud is an unethical behaviour in the relationship between money ethics and accounting fraud, it is contrary to individuals who have a low religious understanding and beliefs (religiosity). Strong religious beliefs are expected to prevent illegal behaviour through guilty feelings, especially in terms of committing fraud, so that someone considers that life success was not only measured by how much money he earns (Grasmick et al., 1991).

In harmony with self-monitoring and self-control, ultimately religion (religiosity) can affect one's feelings to be more peacefully, because people who have high religiosity tend to include God in every step of their way. The heart becomes loose and not burdened, because every problem faced, for example compensation unsuitability with what is expected, will make the individual surrenders everything to God, since the individual assumes that everything happened on earth has been destined by God (Aghili and Kumar, 2008).

Besides, religious-oriented individuals (religiosity) view that work is a worship to bring them closer to God, so even though there is an opportunity to do something that violates ethics, for example there is an opportunity to commit fraud due to weaknesses in the company's internal control system, the individuals do not will do something that violates ethics. This is due to religious values embedded within them so as to assume that obedience to religious norms will get a reward from God, thus motivating these individuals in controlling their behaviour.

Based on the description, the study hypothesis can be derived as follows:

H4: There is an effect of suitability of compensation, money ethics and internal control systems on accounting fraud among regional officials mediated by religiosity.

\section{Study Methods}

The data sources used in the study were primary data in the form of opinions, attitudes, experiences or characteristics of respondents (subjects) and the instrument used was a questionnaire. The measurement of variables in this study consisted of independent variables, namely suitability of compensation, money ethics and effectiveness of internal control system, with moderating variable of religiosity and dependent variable of accounting fraud.

Data collection in this study was conducted by distributing questionnaires to the officials of Regional Work Units of Serang City and Regency. Data analysis used Structural Equation Modelling (SEM) with SmartPLS program. 


\section{Results and Analysis}

Data analysis using SmartPLS has three criteria to assess the outer model, Convergent Validity, Discriminant Validity and Composite Reliability. Convergent validity of the measurement model with reflexive indicators is assessed based on the correlation between the item score/component score estimated by PLS software. Based on the results of data processing using SmartPLS, it could be explained the value of outer loading or correlation between constructs with compensation suitability variable, money ethics and the effectiveness of internal control system, with moderating variable of religiosity and dependent variable of accounting fraud As a whole, the Discriminant Validity and Composite Reliability were sufficient because the outer loading value was above 0.50 .

Table 1. Results for inner weights

\begin{tabular}{|c|c|c|c|c|c|}
\hline Information & $\begin{array}{l}\text { Original sample } \\
\text { estimation }\end{array}$ & $\begin{array}{l}\text { Mean of } \\
\text { sub-samples }\end{array}$ & $\begin{array}{l}\text { Standard } \\
\text { deviation }\end{array}$ & T-Statistic & Hypothesis \\
\hline $\begin{array}{l}\text { The Suitability of Compensation }-> \\
\text { Accounting Fraud }\end{array}$ & -0.285 & -0.266 & 0.098 & 2.922 & Be accepted \\
\hline Money ethics -> Accounting Fraud & 0.583 & 0.583 & 0.063 & 9.221 & Be accepted \\
\hline $\begin{array}{lll}\text { Internal Control } & \text { System } & -> \\
\text { Accounting Fraud } & & \end{array}$ & -0.580 & -0.572 & 0.040 & 14.631 & Be accepted \\
\hline Religiosity $->$ Accounting Fraud & -0.128 & -0.113 & 0.078 & 2.654 & Be accepted \\
\hline
\end{tabular}

Source: Output of SmartPLS

The parameter significance for rejecting and accepting the hypothesis proposed was \pm 1.96 . Based on the estimated output for testing structural models, it could be seen that compensation suitability had a negative effect on accounting fraud $(2.922>1.96)$; money ethics had a positive effect on accounting fraud (9.21 > 1.96); internal control system had a negative effect on accounting fraud (-2.6654 > -1.96); religiosity had a negative effect on accounting fraud $2.654>-1.96$ (Table 1).

The R-square value of the accounting fraud construct, wherein the higher the R-square, the greater the contribution of independent variables in explaining the dependent variable so that the structural resistance was better. The accounting fraud variable had an R-square value of 0.785 which meant that $78.5 \%$ of the accounting fraud variable could be explained by the suitability of compensation, money ethics, effectiveness of the internal control system, while the remaining $21.5 \%$ was explained by other variables outside of this study.

\subsection{Direct Effect of Suitability of Compensation on Accounting Fraud}

The results of this study states that suitability of compensation had a negative effect on accounting fraud, this meant that the more suitable the compensation received by employees, the lower the possibility of accounting fraud opportunity, since compensation received by the employees were in accordance with their expectations. This was a determining factor of the welfare level that was able to encourage employees to perform optimally so as to reduce deviant behaviours and actions that were not conform to ethical norms and characters (Tang, 2002).

In this regard, the company should design an appropriate compensation suitability system without burdening the company, since with appropriate compensation the employees will provide optimal performance to the company. Conversely, if the company does not provide compensation in accordance with employee expectations, it often encourages the employees to conduct unethical things. To meet their needs, they must try to get compensation from other sources. This was one of the factors that encouraged employees to commit accounting fraud (Tang, 2002).

\subsection{Direct Effect of Money Ethics on Accounting Fraud}

The results of this study showed that money ethics had a significant positive effect on accounting fraud. This meant that the higher the someone's money ethics could have a direct effect on accounting fraud behaviour since the person felt that accounting fraud was an acceptable action and the usual thing, and the person put money as top priority so that accounting fraud was an ethical action.

The results of this study are consistent with the study conducted by Lau et al. (2013) which showed that someone who had high money ethics viewed accounting fraud as an ethical action. The results of this study are also in accordance with previous study conducted by Tang (2002) and Tang \& Chiu (2003).

\subsection{Direct Effect of Internal Control System on Accounting Fraud}

The results of this study concluded that the application of internal control system had negative effect on accounting fraud. This meant that the better the implementation of the internal control system in the company, the smaller the 
opportunity for employees to commit accounting fraud, because accounting fraud was influenced by the presence or absence of opportunities to do so. These opportunities could be minimized by effective internal control.

The results of this study are in accordance with the analysis in agency theory. Agency theory explains the organization as a contractual relationship between managers and principals that are loaded with various interests from each party. When the interests of one party are disrupted to be fulfilled, then it is possible for them to conduct deviant behaviours. Therefore a structure that can limit managerial behaviour is needed. Besides, with the implementation of an effective internal control system, the process carried out provides adequate assurance about the achievement of the reliability of financial statements, compliance with the law, and the effectiveness and efficiency of operations, thereby reducing accounting fraud (Meutia, 2017).

\subsection{Direct Effect of Religiosity on Accounting Fraud}

The results of this study concluded that religiosity had a negative effect on accounting fraud. It meant that the religious values inherent in the individual person of an employee could suppress the occurrence of actions that are not in accordance with religious teachings. The role of religion could influence individual attitudes, including in behaving towards business financial reporting. Religiosity of someone would affect the level of responsibility for information that will be reported related to increasing honesty, fairness in information, so that it could increase social and environmental responsibilities.

The value of religiosity causes a person not to work just to meet his material needs, but more than that, work can be seen as a service for the benefit of many people and the environment. Religiously bound individuals hold more broad corporate social responsibility than individuals who are not religiously bound.

4.5 Indirect Effect of Suitability of Compensation, Money Ethics, and Internal Control System on Accounting Fraud Among Local Government Officials When Mediated by Religiosity

The following is a table of Suitability of Compensation, Money Ethics, and Internal Control System on Accounting Fraud among Local Government Officials when Mediated by Religiosity.

Based on table 2, the magnitude of the indirect effect of suitability of compensation on fraud among the local government officials through religiosity was -0.124 . Meanwhile, the direct effect of suitability of compensation on the religiosity of local government officials was -0.128 . This showed that religiosity could mediate the indirect effect between the suitability of compensation and accounting fraud among local government officials. This meant that religiosity acted as a guide for human life in regulating humans and God, humans and humans, humans and their environment relations and even prevented deviant behaviours such as stealing. Prevention can be possible since people who have high religiosity have strong self-control, and religious teachings that they believe can prohibit these actions (Cohran, 1988; Desmond et al., 2013).

Furthermore, the magnitude of the indirect effect of money ethics on fraud among local government officials through religiosity was -0.005 . Meanwhile, the direct effect of suitability of compensation on the religiosity of local government officials was -0.128 . This showed that religiosity could mediate the indirect effect between money ethics and accounting fraud among the local government officials. This meant that the high role of religious values in an individual could reduce one's love of money which finally could reduce his desire to commit unethical accounting fraud. This is due to strong religious commitments and beliefs can prevent unethical actions through guilty feelings (Grasmick et al., 1991).

Table 2. Indirect effect of the suitability of compensation on accounting fraud of local government officials when mediated by religiosity

\begin{tabular}{llllll}
\hline Lane & Information & $\begin{array}{l}\text { Direct Impact } \\
\text { SC-AF } \\
(\mathrm{A})\end{array}$ & $\begin{array}{l}\text { Direct Impact } \\
\text { SC-R } \\
(\mathrm{B})\end{array}$ & $\begin{array}{l}\text { Direct Impact } \\
\text { R-AF } \\
\text { (C) }\end{array}$ & $\begin{array}{l}\text { Indirect } \\
\text { Impact } \\
\text { (BXC) }\end{array}$ \\
\hline 1 & $\begin{array}{l}\text { The Suitability of Compensation }-> \\
\text { Religiosity -> Accounting Fraud }\end{array}$ & -0.285 & 0.971 & -0.128 & -0.124 \\
\hline 2 & $\begin{array}{l}\text { Money ethics -> Religiosity -> } \\
\text { Accounting Fraud }\end{array}$ & 0.583 & -0.044 & -0.128 & -0.005 \\
\hline 3 & $\begin{array}{l}\text { Internal Control System -> } \\
\text { Religiosity -> Accounting Fraud }\end{array}$ & -0.580 & 0.043 & -0.128 & -0.005 \\
\hline
\end{tabular}

Source: Processed Primary Data in 2018 
The magnitude of the indirect effect of internal control system on fraud among local government officials through religiosity was -0.005 . Meanwhile, the direct effect of suitability of compensation on the religiosity of local government officials was -0.128 . This showed that the role of religious values embedded in an individual could further increase the effectiveness of internal control system designed by the company. Someone who has high religious values will not work just only to meet his material needs, but more than that, work can be seen as a service for the benefit of many people and the self monitoring environment fosters strong self-control attitude that has an impact on right and good attitudes and behaviours, so that deviant behaviours will not occur.

\section{Conclusions and Recommendations}

Suitability of compensation had a negative effect on accounting fraud among the regional officials in Serang city and Regency. Money ethics had a significant positive effect on accounting fraud among the regional officials in Serang city and Regency. Internal control system had a negative effect on accounting fraud among the regional officials in Serang city and Regency. Religiosity had a negative effect on accounting fraud among the regional officials in Serang City and Regency. Suitability of compensation, money ethics and internal control systems were proven to be antecedent variables of religiosity participation. The study results showed that suitability compensation, money ethics and internal control system variables had indirect effect on accounting fraud.

The euphoria of regional autonomy turned out to have many negative impacts. One that stands out is the emergence of institutional crime, both executive and legislative. One crime that is often carried out in the form of accounting fraud is related to corruption. Ccorruption among bureaucrats is indeed difficult to avoid, because political scandals on power and bureaucracy really played a very large role. Study on accounting fraud related to corruption is an interesting topic, because the act of handling accounting fraud requires a better, comprehensive and integrated effort.

\section{References}

Aghili, M., \& Venkatesh, K. G. (2008, April). Relationship between Religious Attitude and Happiness among Professional Employees. Journal of the Indian Academy of Applied Psychology, 34, 66-69.

Cohran, J. K. (1988, October). The Effect of Religiosity on Secular and Ascetic Deviance. Sociological Focus, 21(4), 293-306. https://doi.org/10.1080/00380237.1988.10570527

Desmond, S. A., Ulmer, J. T., \& Bader, C. D. (2013). Religion, Self Control, and Substance Use. Deviant Behavior, 34(5), 384-406. https://doi.org/10.1080/01639625.2012.726170

Grasmick, H. G., Bursik, R. J., \& Cochran, J. K. (1991). Render Unto Caesar What Is Caesar's: Religiosity and Taxpayers' Inclinations to Cheat. Sociological Quarterly, 32, 251-266.

Ismail, T., Meutia, M., \& Ummi, N. (2019). Enabling management control in improving the performance of SMEs. Management Science Letter, 9(10), 1823-1832. https://doi.org/10.5267/j.msl.2019.6.009

Ismail, T. M., Bokhori, A., \& Fajri, E. (2018). Building Innovation Capability through Triple Helix Model Sinergy to Improve SME's Marketing Performance. International Journal of Civil Engineering and Technology, 9(7), 1403-1412.

Lau, T. C., Choe, K. L., \& Tan, L. P. (2013). The Moderating Effect of Religiosity in the Relationship between Money ethics and Tax Evasion. Asian Social Science, 9(11), 213-220. https://doi.org/10.5539/ass.v9n11P213

Leopold, J. (2000). Human Resources in Organization. Ashford Colour Press Ltd. Harlow-England.

McGuire, S. T., Omer, T. C., \& Sharp, N. Y. (2011, April). The Impact of Religion on Financial Reporting Irregularities. https://doi.org/10.2139/ssrn.1548154

Meutia. (2017). Proactive attitude and organizational performance. International Journal of Economic Perspetive, $11(1)$.

Sloan, A. (2002). The Jury's In: Greed Isn't Good. News Week, 37.

Tang, T. L. P. (2002). Is the Love of Money the Root of All Evil? Or Different Strokes for Different Folks: Lessons in 12 Countries. Paper Presented to the International Conference on Business Ethics in the Knowledge Economy. Hongkong. China.

Tang, T. L. P., \& Chiu, R. K. (2003). Income, Money ethics, Pay Satisfaction, Commitment, and Unethical Behaviour : Is the Love of Money the Root of Evil for Hongkong Employees?. Journal of Business Ethics, 46, 13-30. https://doi.org/10.1023/A:1024731611490 